\title{
Future Energy Security for Kazakhstan: A Case Study of Brazil
}

\author{
Hor Ka Wai Christopher' ${ }^{1}$, Fatima Kukeyeva ${ }^{2}$, Malik Augan $^{3}, K_{\text {Kuralay Baizakova }}^{4}$, Duman Zhekenov \\ ${ }^{1}$ PhD student al-Farabi National University, 95 Karasai Batyr, 050026, Kazakhstan, Almaty; \\ ${ }^{2}$ Professor, Doctor of History, Prof. of International Relation Department of al-Farabi Kazakh National University, \\ Kazakhstan, Almaty, 95 Karasai Batyr, 050026; \\ ${ }^{3}$ Professor, Doctor of History, Prof. of International Relation Department of al-Farabi Kazakh National University, \\ Kazakhstan, Almaty, 95 Karasai Batyr, 050026; \\ ${ }^{4}$ Professor, Doctor of History, prof of International Relation Department of al-Farabi Kazakh National University, \\ 050026, Kazakhstan, Almaty;
}

${ }^{5}$ PhD in International Relations, Deputy Dean of International Relation Department of al-Farabi Kazakh National University, Kazakhstan, Almaty, 95 Karasai Batyr, 050026.

\begin{abstract}
As a petro-state, the Republic of Kazakhstan is the largest greenhouse gas emitter in Central Asia. While the republic has a vast cumulative potential of renewable energy sources, the latest data indicates that the share of renewable energy sources in electricity production remains low at $2.3 \%$ in 2019. This paper aims to explore the energy security implications of Kazakhstan's target of raising the share of renewable energy source to $50 \%$ by 2050 . Building on existing work on energy for sustainable development, our research question is: how does diversification of energy sources in Kazakhstan affect the republic's pursuit of energy security? Brazil's accomplishment in energy diversification as an oil-exporting country is used as a case study, demonstrating the growing trend, and risks, of regional electricity integration to forge a sustainable and coordinated energy security policy.
\end{abstract}

Keywords: Energy Diversification, Renewable Energy, Energy Security, Kazakhstan, Brazil, Case Study, Comparative Study

\section{INTRODUCTION}

The concept of geopolitics has perpetually been keen on energy-related subjects since conventional energy sources like natural gas, oil, and coal constitute physical geographical variables of strategic significance, providing the advance of great powers, the development of alliances and, in several cases, to the appearance of disputes and wars. Given Michael Klare (2002), energy resources will certainly substitute military power. Moreover, it will be the reason for armed fights and nations would even utilize military power to control energy resources.[1] The unequal geographic distribution of coal, oil and natural gas reserves creates a clear separation between net-exporters and net-importers, setting up oligopolistic markets where producers hold considerable market power and where consumers secure access to resources. In this connection, countries, along the global supply chains of petroleum, can be divided into three categories: i). energy-exporting nations (Saudi Arabia, Russia, the United States, Venezuela, etc.) whose economies dependent on energy revenues; ii). energy-importing nations with high energy consumption (Japan, EU countries, China, India) notwithstanding their own energy resources; iii). transit countries are holding strategic positions or maritime chokepoints (Georgia, Turkey, Singapore, etc.) for energy transport. A pattern of interdependence is developed when energy is traded between exporting and importing countries via pipelines or shipping routes. The importance of fossil fuels in universal trade can barely be exaggerated neither can their crucial role in feeding industrial processes and advanced economies be overlooked.

However, technological advances unlocked new resources and brought about significant changes in global energy markets. The expansion of renewable energy resources can modify energy dependencies between current producers, consumers, and transit countries. As its resources (in the format of sunlight, wind, rain, tides, waves, and geothermal heat, etc.) are widely distributed, supply-side geopolitics are expected to be less influential than in the fossil-fuel era. Nations that today rely massively on fossil fuel imports can utilize renewable energy to secure strategic and economic interests. The growth of its deployment in the power sector has already outpaced that of any other energy source, virtually at the cost of nuclear power and coal. Where this is happening, pricing dynamics in wholesale power markets are remarkably shifting - generally, pushing energy costs downwards. Significant changes that are occurring in the global energy system will be able to affect nearly all countries and have vast-ranging geopolitical outcomes, including the emergence of new energy leaders around the world, changing patterns of trade and the development of new alliances.

The notion of Kazakhstan as a bridge transcending geographic regions and civilizations is presented as a justification for the republic's multiple international engagements. Its multi-vector foreign policy, as displayed in its engagement in multilateral organizations and also in its bilateral relations, has profited the republic without creating adversaries in international politics. Its vast coal, oil, natural gas and uranium reserves have enabled it to gain leverage in managing difficult relations with neighbouring Russia and China, and form a strategic partnership with the United States and the European Union. 
Home to the world's 12th-largest oil reserves, Kazakhstan might well appear to possess low motives to invest in diversifying away from fossil fuels. Oil exports have been running the economic development of Kazakhstan for roughly thirty years. Including an extraordinary 40-year reserves-toproduction $(\mathrm{R} / \mathrm{P})$ ratio for oil, $35 \mathrm{R} / \mathrm{P}$ for natural gas, and 150 $\mathrm{R} / \mathrm{P}$ for coal, it is no wonder that fossil fuels have primarily reached the growth in domestic electricity consumption.[2] Such overwhelming reliant on exhaustible energy resources has placed Kazakhstan at 60th (out of 128 countries) on the 2019 World Energy Security Rankings by the World Energy Council, far below the renewable-intensive Nordic states such as Sweden, Denmark and Finland.[3] Coal alone is responsible for covering more than $70 \%$ of the republic's electricity demand, making Kazakhstan also the world's 14thlargest emitter of greenhouse gases per capita in 2018.[4]

When First President Nursultan Nazarbayev announced that the republic would implement green economic policies through its "Strategy 2050" development plan in 2012, Kazakhstan has established itself a challenging aim: it seeks to be one of the top 30 competing developed countries throughout the world by 2050 whereas gradually "greening" vital economic sectors. Renewable energy policy has since been developed in a decidedly top-down fashion as best illustrated in signing the Paris Climate Change Agreement in 2016 and the "future energy" theme of the EXPO 2017 Astana. The republic's National Concept for Transition to a Green Economy also sets a bold timeline to move from under $1 \%$ renewable energy sourcing when it was adopted in 2013 to $3 \%$ by $2020,30 \%$ by 2030 , and $50 \%$ by 2050 , promoting a more decentralized, balanced and environmentally friendly energy supply system.[5] With an active adoption of a new legal framework and an auction system for renewable energy projects to attract foreign investment for the energy transition, since 2014 electricity generation at new solar, wind and small hydropower plants has increased by 155 times, while their total installed capacity has reached 1042 megawatts (MW), or about $2.3 \%$ of the total installed capacity of all power plants operating in the country, making the 2020 target achievable.[6] This recognizes not only the republic's abundant fossil fuel sources but the highly favourable geography for renewable energy development.

This paper aims to explore the energy security implications of Kazakhstan's target of raising the share of renewable energy source to $50 \%$ by 2050 . Given Brazil is the world's 9th biggest crude oil producers but with one of the highest global shares of renewable energy in its energy matrix, it is not an exaggeration to say that the country is seen as a global energy and environmental leader. Brazil's accomplishment in energy diversification provides a valuable case study for Kazakhstan to pursue a sustainable and coordinated energy security policy.

\section{LITERATURE REVIEW AND HYPOTHESIS}

This section presents a literature review to address our research question. Besides clarifying key concepts and their relation, specific energy security issues faced by Brazil and Kazakhstan in association with renewable energy development are also reviewed. Since the study and practice of renewable energy in the context of international relations are a relatively new research topic, our literature review includes relevant academic papers as well as industrial reports produced by authoritative bodies to facilitate our analysis.

Definition of energy security. The concept of energy security is notably hard to define due to different energy relationships among states as "importing countries", "exporting countries" or "transit countries". Yet, its core dimensions are relatively clear. At its narrowest, energy security is generally synonymous with "the uninterrupted availability of energy sources at an affordable price" as defined by International Energy Agency (IEA).[7] For World Energy Council, energy security is "to satisfy current and future energy requirement reliably, and bounce back quickly from system crashes with minimum disruption to supply."[8] According to Bielecki (2002) energy security implies to present sufficient and secure supplies of energy consistently satisfying the need of the global economy at an affordable cost.[9] Bohi and Toman (1996) explain energy insecurity as the loss of welfare stemmed from a change in the cost or physical abundance of energy.[10] Percebois (2013) and Gnansounou (2008) emphasize on the importance of avoiding dependence and vulnerability to ensure energy security[11], while Winzer (2012) focuses on energy supply continuity, encompassing continuity of commodity supply, continuity of service supply, and the political-economic impact of discontinuity.[12]

At its broadest, Sovacool and Mukherjee (2011) argue that energy security should include dimensions such as environmental sustainability, social acceptability, technology development and regulatory stability. Common issues are climate change and local pollution, public approval and equity, adequate investments in research and development (R\&D) and networks, transparency and commitment in turn. The policy framework with which energy security must be guaranteed is controversial.[13] According to Egenhofer and Legge (2001), some decision-makers put their trust in market instruments for enhancing the energy supply matrix. In contrast, others recommend more governmental intervention claiming that markets fail to guarantee sufficient and continued levels of energy security.[14] Owen (2004) describes energy supplies security an essential element for the environmental, economic, and social aims of sustainable development policies. from his standpoint, energy security peril can be categorized as domestic and strategic system risks.[15]

There are the four "As" of energy security (acceptability, affordability, availability, and accessibility) launched by the Asia Pacific Energy Research Centre (APERC, 2007)[16] but Cherp and Jewell (2011 \& 2014) considered that these four factors do not adequately address security questions.[17] Hughes (2009) introduced the four "Rs" concept, clarifying that energy security must be on the basis of "review (understanding the problem), decrease (using less energy), replace (shifting to secure sources), and restrict (restricting new needs to secure sources)".[18] Dannreuther (2017) treats energy security as a value that is continually in dynamic conflict with other core values, highlighting the social, economic and political contexts which are essential for a fuller appreciation of contemporary energy challenges.[19] Cohen, Joutz, and Loungani (2011) argue that there is a relationship 
between energy diversification and energy security.[20]

According to $\mathrm{Hu}$ and $\mathrm{Ge}$ (2014), based on a China case application, the assessment of energy security is explained in terms of three aspects. The first aspect is the stability of energy supply, indicating the stability of meeting the energy security guarantee of standard requirements applied for national survival and development, which includes the ration of energy production and consumption, the diverse index of production, the risk index of transportation, market liquidity, foreign dependence, and etc. Another aspect is the security of energy usage, which implies that the use and consumption of energy must not endanger human survival and the development environment. This aspect includes energy consumption per GDP, renewable energy usage, carbon consumption, the structure of energy use, the economy. The final aspect concerns the stability of energy need, which is the basis of energy supply guarantee security, and the essential opening point for energy security investigation. It includes industrial energy use intensity, economic development, industrial structure, per capita consumption, and population growth.[21]

International relations and energy security. As stated in the International Renewable Energy Agency (IRENA) report "A New World" (2019), concerns over energy security have marked the conduct of international relations, the formation of alliances, protection of national interests and defence planning.[22] As a policy problem, Yergin (1991, 2006) argues that energy security emerged in the early 20th century in connection with supplying oil for armies and is assessed as an issue of power interest that has become a question of national strategy.[23] According to Shaffer (2009), when the strategic importance of energy security coincides with different leverages of countries with different roles in the energy game as producers, consumers and transit countries, the interaction between energy security and foreign policy becomes inevitable. To the extent that the states are interdependent in energy, their foreign policies and energy strategies are also interlinked. The physical ties through expanded energy infrastructures and political ties through long-term contractual commitments between suppliers and consumers create "room for politics."[24] Müller-Kraenner (2008) comments that, ensuring the uninterrupted and affordable energy supplies at the domestic level, defining the rules of the game for the energy markets now and in the future at the international level are today's tough realpolitik. Thus "alliances are formed not with those that we like, but with those that we need.'”[25]

As the world has rapidly moved into an era of renewable energy, according to Scholten (2019), the study or field of the geopolitics of renewable energy is at its very essence about how the geographic and technical characteristics of renewable energy systems shape interstate energy relations, i.e. the strategic realities and policy considerations of producer, consumer, and transit countries and energy related patterns of cooperation and conflict between them.[26] Hache (2018), from a macroeconomic point of view, claims that the new challenges induced by energy transition policies could paradoxically turn out being as complex as today's geopolitics of energy. Local and decentralized relations could add a new geopolitical layer to current traditional actors. Technical, economic, sociological, behavioural, spatial and legal dimensions could also complicate the emerging puzzle. A massive diffusion of renewables into the world's energy matrix could also lead to new, unexpected interdependencies such as dependencies to critical materials, a new geopolitics of patents and the implementation of a renewable diplomacy.[27]

Renewable energy and energy security in practice. With energy security increasingly entangled with sustainable development and climate change mitigation, according to a joint report produced by IRENA and IEA (2018), renewable energy, in combination with energy efficiency, now form the leading edge of a far-reaching global energy transition. The growth of its deployment in the power sector has already outpaced that of any other energy source, including fossil fuels, which include oil, coal and natural gas. In many markets around the world, intermittent renewable energy sources primarily wind and solar - are gaining an increasing share of electricity supply, mainly at the expense of coal and nuclear power. Where this is occurring, pricing dynamics in wholesale power markets are significantly changing — in general, driving energy prices downward.[28] A separate IRENA report (2019) proposes that, increasing energy security through renewable energy deployment may change the dynamics between energy exporters and importers. It will also diminish the role of oil and natural gas in international politics. Ensuring the security of energy supply becomes more a matter of domestic governance, rather than an international security priority. Countries that achieve energy independence will also be less vulnerable or beholden to their suppliers and will therefore be able to pursue their strategic and foreign policy goals more independently.[29]

Olz, Sims and Kirchner (2007) comment that the contribution of renewable energy makes to energy security is less widely recognized in contrast to its variability. Their study thus aims to show how in electricity generation, heat supply, and transport, renewable energy can enhance energy security and suggesting policies that can optimize this contribution. They argued that, for those countries where growing dependence on imported gas is a significant energy security issue, renewable energy sources can provide alternative, and usually indigenous, sources of electric power as well as displacing electricity demand through direct heat production. Renewable energy sources also, usually, increase the diversity of electricity sources, and through local generation, contribute to the flexibility of the system and its resistance to central shocks.[30]

According to Johansson (2013), renewable energy systems can improve some aspects of security, but they will not automatically lead to the removal of all types of security problems and new problems will most certainly arise. He argues that renewable energy sources do not suffer from the same long-term resource availability problems as finite fossil resources and their geographical location is less concentrated, but other issues such as dependence on variable flowing resources and competition for scarce land resources will grow in importance. Many security issues related to energy are also dependent on the energy carrier rather than the energy 
resource and on the existence of effectively functioning institutions and regulations. New interdependencies will appear and will have to be handled within future international and bilateral institutional frameworks.[31]

Abolhosseini, Heshmati and Altmann (2014) considers energy security as one of the main drivers for using renewable energy technologies, overcoming the level of insecurity due to supply disruption for fossil fuels and estimated costs associated with security improvement for nuclear power.[32] In this connection, according to a report produced by American Council on Renewable Energy (ACORE) in 2018, renewable energy provides a growing and vital contribution to national security. Unlike conventional methods of producing electricity, renewable energy generators do not rely on fuel supply chains that can be disrupted intentionally or by natural events. Unlike combustible fuels, renewable energy does not pose a risk of dangerous leaks or explosions that threaten human health and public safety. Renewable energy generation facilities can also be constructed within a short timeframe. Typically dispersed throughout different regions, they are also less vulnerable to acts of terrorism. Additionally, renewable energy generators enhance the reliability and resilience of the entire electrical grid during high-impact events, especially when combined with energy storage and other advanced grid technologies (i.e. smart grid). In cases where continuity of power supply is vital for national defence operations, renewable power and enabling technologies, such as storage, can be combined to form self-sustaining microgrids.[33]

Scholten (2018) argues that the global transition to renewable energy will put electricity centre stage since renewable energy is overwhelmingly subject to electrification in supply and in usage. To reduce costs and to prevent shortages in the event of a still or overcast day, countries may develop a tendency to integrate their electricity grids regionally for an optimized electricity security cooperatively.[34] Moreover, while at first glance it might sound like adding too much renewable energy could destabilize the delicate balance of the electric grid due to its intermittency, Fares (2015) comments that renewable energy actually becomes more predictable as the number of renewable generators connected to the grid increases together with a mixture of sources that complement each other to roughly equal our total energy demand over the day. This is technically possible because continental wind energy tends to peak at night, coastal wind energy tends to peak during the day, and solar can peak at various times over the day, depending on which way it is oriented.[35] As a result, both Scholten and Fare agree that geographic diversity is decisive for sustainable renewable power generation. In this era of energy transition, globalized energy world is expected to gradually become more regionally focused, though global trade will continue.

Renewable energy and energy security in Brazil. Brazil's government is heavily involved in the energy sector: it owns half of Brazil's major electric utility Electrobras, and half of the oil company Petrobras. President Bolsonaro said, "electric power is vital, and therefore cannot be handed over to other countries," and he added "I'm in favour of privatizing many things in Brazil, but not in the energy sector.'[36] A 2014 research, conducted by Swedish Agency For Growth Policy
Analysis, comments that energy security or energy supply assurance, preferably from internal sources (so as to limit the effects of international supply shortages), has been a longstanding goal of the Brazilian government. The successful National Alcohol Fuel Program (ProÁlcool), launched following the 1970's oil crisis, is one example of how past government actions were geared towards assuring internal supply of energy. Together with the availability of hydropower in its primary energy matrix, the country has been able to achieve significant sustainable development while keeping its $\mathrm{CO} 2$ emissions related to the energy-sector at relatively low levels.[37] Pereira et al (2012) illustrates that Brazil possesses major potential in terms of renewable energy resources (solar, wind, biomass and hydropower) and Pre-Salt fossil resources (destined primarily for export). These sources form most of the Brazilian strategy aimed at satisfying the demand for $6300 \mathrm{MW}$ of fresh capacity per year arising out of projected economic growth of $5 \%$ per year over the next 10 years.[38] Santos (2018) presents an overview of concepts and policies related to energy security and regional integration in MERCOSUR (South American regional economic organization), of which Argentina, Brazil, Paraguay and Uruguay are member states. Focusing on MERCOSUR countries, including Venezuela and Bolivia, a general comparative analysis was carried on the energy markets and the physical infrastructure of these countries (and of South America, as a whole). Framework Agreement on Energy Cooperation (2005) is a milestone, highlighting the possibility of concluding regional, sub-regional or bilateral agreements in the areas of (i) commercial exchange of hydrocarbons; (ii) interconnection of the electric transmission networks; (iii) interconnection of pipeline networks and other hydrocarbon pipelines; (iv) cooperation in the exploration, exploitation, and industrialization of hydrocarbons; and (v) renewable energy sources and alternative energy sources. Santos argues that MERCOSUR's energy integration should be promoted because it reduces both the need to invest in the expansions of power supply and the socio-environmental impacts associated to electricity projects in the region, implying the priority in pursuing cooperative energy security for the continent.[39]

Renewable energy and energy security in Kazakhstan. In Kazakhstan, the Ministry of Energy and Mineral Resources was the responsible governmental agency for energy policies until March 2010 when it was dissolved and replaced by the Ministry of Oil and Gas and the Ministry for Industry and New Technologies, signifying the state's prominent presence in the republic's energy sector. Zhiyenbayev (2018) produces a study of Kazakhstan's energy security in the period of 20002015 in 4 dimensions, namely "availability", "affordability", "efficiency", and "environmental stewardship". Renewable energy, although not specifically discussed, is embedded as one of the energy consumption indicators in "affordability". The analysis indicates Kazakhstan has been the strongest in "availability" and "affordability", while weakest in "efficiency" and "environmental stewardship". The analysis also shows a strong co-dependency between energy security and economic security of Kazakhstan, which is caused by the large influence the fuel and energy complex of the country has on the whole national economy.[40] Mantel (2016) addresses the key aspects of energy security policy in Kazakhstan, 
suggesting that an increase in the use of the renewable energy sources is crucial for reducing the country's dependence on oil and gas supplies. Greater reliance on renewable energy would improve economic and environmental sustainability, ensure increased energy security, and help create the conditions necessary for enhancing collaboration in Central Eurasia, as well as cooperation with Central Asian and EU states, in the energy sector. By reviewing several dimensions of the Kazakhstan oil and gas industry and its impact on the country's energy security policy, Mantel makes recommendation for measures that might prove effective for introducing new "green" technologies aimed at limiting consumption of non-renewable natural resources and introducing a larger-scale renewable energy production.[41]

Hypothesis. This paper aims to examine the effects of diversification of energy sources in Kazakhstan on the republic's pursuit of energy security. Our literature review resulted in a hypothesis with energy security implications: regional electricity cooperation and integration are essential to energy security with an increase deployment of renewable power generation.

\section{METHODOLOGY AND THEORETICAL FRAMEWORK}

When analyzing the questions posed in this paper, the authors apply the case study method. A case study of Brazil helps identify the features associated with energy diversification in the context of the state energy security, providing a comparative examination of the assets and liabilities of renewable energy development in Kazakhstan.

Based on the findings of our literature review, energy security is not equivalent to energy self-sufficiency or self-reliance but implies to the provision of a state with energy resources necessary for the functioning of the economy and the satisfaction of the needs of the population, and the availability of conditions for an effective and profitable trade exchange of these resources in the international market.[42] Energy security is thus a key component of national security for all states. Yet, due to their different relationships with energy as either "importing countries", "exporting countries" or "transit countries", energy policy and governance are not identical across the world. Typical concerns relate to the finite and geographically concentrated nature of oil and natural gas reserves, policies of diversification of source, origin, and route, price volatility due to political instability in producer countries, and a variety of technical, human, and natural risks to infrastructure. In this connection, avoiding dependence and vulnerability are key. For Kazakhstan, as an exporting country whose economy is primarily dependent on oil extraction, the commodities crash of 2014 and a growth slowdown in the republic's two biggest trade partners, Russia and China, laid bare its overdependence on hydrocarbons and the persistent weakness of other sectors of its economy. The depletion of oil and natural gas reserves will also reduce its energy security sustainability in the long term. Diversification of its energy sources via development of alternative energy sources, especially renewable energy for a post-carbon economy, has thus become a strategic trend of transition in Kazakhstan.

Neorealism plays a key role in the interpretation of international security, in which energy access is inseparable from state economic and military power, compositing national power. States regard capabilities as the ultimate basis for their security since they are unable to predict the intentions of other states, and the need to balance a hegemon provides the incentives for the disadvantaged states to cooperate.[43] Based on the notion that states are central actors in the international system, neorealists do not take into account of the international energy markets but see national power as crucial to security. However, market forces in the last few decades have been demonstrated through their decisive effects on the energy policy trends in accordance with the requirements of both consumer countries and energy suppliers. Two paradoxical but converging trends can be identified: on the one hand, the increasing role of liberal markets and nonstate institutions in energy security; and on the other, constant intervention of governments in the energy sector as part of national security strategies. For Kazakhstan, two possible scenarios can be conceptualized: the republic continues its reputation as a petro-state, focusing on energy exports in competition with other exporting countries for market share but also energy diversification by developing alternative energy sources as a gesture to follow the global trend of energy transition, or, most probably, strives to develop both directions in parallel to maximize its energy security and strengthen its economic adaptability with the member nations of the Organization for Economic Co-operation and Development (OECD). In both cases, the agenda involve stimulation for long-term investments, improvement in energy efficiency and management of problems in associated with oil and natural gas reserves depletion in the long term as First President Nazarbayev proposed in "Kazakhstan 2050 Strategy".

Thus, the use of the case study method allows one to analyze the issues embedded in energy diversification in accordance with specific theoretical propositions. The case study method used in this paper is typical, seeking rival explanations and falsifying hypotheses with theoretical explanations. The comparative method enables us to detect analogies in cases, to reveal manifestations of certain phenomena and to study all possible variants in energy diversification in Kazakhstan.

\section{ANALYSIS OF ENERGY STRATEGIES IN BRAZIL AND KAZAKHSTAN}

In this section, we presents a brief overview of the energy strategies in Brazil and Kazakhstan, including the reasons behind their pursuit of energy diversification, the institutional change and policy framework for an optimized energy security, foreign and regional energy relations, and their favourable geographical conditions for renewable energy development.

Energy strategy in Brazil. The discovery of oil and gas field in the province of Pre-Salt in 2007, considered as one of the largest in the world in the last three decades, opened a new 
International Journal of Engineering Research and Technology. ISSN 0974-3154, Volume 13, Number 11 (2020), pp. 3718-3731

(C) International Research Publication House. https://dx.doi.org/10.37624/IJERT/13.11.2020.3718-3731

phase in the Brazilian petroleum sector. The country's crude oil exports hit a record high in December 2019 with a total 8.7 million tonnes of crude oil exported, boosted by the presence of major international oil companies that already hold operator status in Brazil.[44] However, Brazil's process of energy diversification began in the 1970s when the country suffered intensely from the oil crisis. With the country importing around $80 \%$ of its oil consumption at the time, the military government that ran the country from 1964 to 1985 adopted aggressive policies with the objective of minimizing Brazil's dependency on imported oil.[45] Among these policies, the implementation of a national programme to produce ethanol from sugar cane as a gasoline substitute in 1975 should be acknowledged as a milestone, as well as hydroelectricity development, nuclear power programmes and energy integration with the country's neighbours.[46] Using alternative sources of energy, Brazil began a process of transition to a low-carbon economy. It is also noteworthy that significant changes had happened to the Brazilian energy sector after the fall of the military government with the beginning of the National Privatisation Programme in 1990, opening the electricity system to competition and private capital for new investments and increase of efficiency. Energy policy in Brazil is the responsibility of the Ministry of Energy and Mines, Ministério de Minas e Energia (MME). The Electricity Regulatory Agency, Agência Nacional de Energia Elétrica (ANEEL), is the regulating body for the electricity market and is also responsible for publishing and managing energy auctions and operating tariff-based schemes across the country. In the early 2000s the energy sector was further divided into regulated and unregulated markets to enable public and private investment, ensuring sufficient investments to accommodate Brazil's growing electricity demand at about 5\% annually. According to the World Bank's data, private energy investments increased considerably after 2009 compared with the years before, from US\$2 billion in 2004, US $\$ 11$ billion in 2009 to US\$31 billion in 2012, until the Brazilian economy experienced a contraction in subsequent years.[47]

Government interventions have been used to achieve other energy policy goals in terms of renewable energy. The Incentive Program for Alternative Sources of Electric Energy (PROINFA), designed in 2002, aims at promoting the diversification of the Brazilian energy matrix, seeking alternatives to increase security in the supply of electricity, in addition to promoting increased electricity generated by sources such as wind, small hydroelectric plants, and biomass burning in the Brazilian National Interconnected Electrical System. This has been complemented by more generous prices paid at government electricity auctions for wind and other renewable power when a legal framework to utilize energy auctions was introduced in 2004. These auction prices, guaranteed by government, support the development of renewable technology that may be uncompetitive in the early stages. From 2002 to 2012, the programme accounted for 132 plants, divided into $533 \mathrm{MW}$ of biomass (21 plants), $1,182 \mathrm{MW}$ of wind (51 units), and 1,157MW of small hydro (62 units) using 20-year contracts.[48] The intention is that these technologies will eventually become cost-competitive with hydropower to meet the growth in electricity demand in the regulated market, and/or to add supplementary energy to increase the system's reserve margin.

From 2012 to 2015 , due to a three-year drought, uncertainty about water supply led to increased diversification in more nonhydroelectric generation technologies, making wind energy the second main source of energy in 2019 after hydroelectricity, with a target to reach 20 gigawatts $(20,000$ MW) by 2022. The latest plan-Plano Decenal de Expansão de Energia (PDEE) 2027-focuses on a significantly increased expansion of solar photovoltaic (PV) capacity, while hydroelectricity capacity remains above 50\%. The PDEE 2027 expects installed solar PV capacity to increase to 8.6 GW by 2027, up from 2.5 GW in February 2019.[49] Brazil currently supports utility-scale PV development through energy auctions conducted by the National Electric Energy Agency. According to the Brazilian Ministry of Mines and Energy, installed power generation capacity is expected to reach $212 \mathrm{GW}$ by 2024 and it will require around $\$ 101$ billion in investments.[50] With the country being 8th in the ranking of countries by investment attractiveness for renewable energy[51], all of the major international major oil firms that operate in Brazil, including Exxon Mobil Corp., BP plc, Royal Dutch Shell and Equinor, have demonstrated their intentions to develop renewable energy projects in the country despite ample oil and gas reserves. Both Germany and China, two of the leading countries in renewable energy production, have also enjoyed strategic partnerships with Brazil respectively in pursuing energy efficiency at policy, financial and technological level.[52]

On the basis of these developments, there is little doubt that Brazil has developed important resources in both fossil and renewable to fulfil its ever-growing energy needs. In the electricity system, Brazil has a total of $160 \mathrm{GW}$ in installed capacity, of which $77 \%$ is from renewable resources, mainly hydropower. Natural gas and biomass represent $9 \%$ each, while nuclear accounts for nearly 2\%.[53] A diversified generation capacity, the flexibility provided by the large hydroelectric plants, wind farms, solar farms, and the existence of interconnections with Argentina, Paraguay, Uruguay and Venezuela are factors increasing the country's energy security. The World Energy Council places Brazil at 19th (out of 128 countries) on the 2019 World Energy Security Rankings.[3]

Energy strategy in Kazakhstan. Prior to independence in 1991, Kazakhstan's local petroleum-producing fields and electric power industry were managed exclusively by stateowned enterprises. To revitalize stagnated industries and attract foreign capital to the country, the Kazakhstan government launched the privatization programme. While the concept of the state-owned (state owns at least $50 \%$ of shares) oil company was initially legislated in 1999 via the revised version of Kazakhstan's Law on Subsoil and Subsoil Use, in 1995 the privatization of power generation facilities was launched. Today, KazMunaiGas is the state-owned oil and natural gas company of Kazakhstan after merging Kazakhoil and Oil and Gas Transportation in 2012, and electric power production in Kazakhstan is carried out by 76 electric power stations of various forms of ownership. National Power Grid, which provides interregional and interstate electric power 
network, remained in state ownership. National Company joint stock company KEGOC, comprising the national dispatch centre systems' operator, has been established in order to manage this grid. The organizational design of the energy industry is divided into policy-making, regulatory and commercial functions: the government acts as a primary policy maker, the Ministry of Energy performs regulatory functions, and the state-owned and private companies in this triangle are supposed to mainly concentrate on commercial goals.

Supported by robust oil production, Kazakhstan is one of the world's most energy-intensive economies. However, the republic has been dependent on unsustainable resource use patterns. The predominance of extractive industries and the associated high levels of energy intensity risk significant damage to land, water, and to air quality in the republic. In 2018, Kazakhstan was the 13th largest coal exporter in the world, 10th crude exporter and 22nd natural gas exporter.[54] Caught between the need for a favourable relationship with its chief export route Russia and the desire to engage with the oilthirsty European Union, United States and China, Kazakhstan attempts to position itself as a global crossroads through its "multi-vector" foreign policy that seeks to "balance the republic's 'diverse range of interests for a sensible equilibrium"" among its allies. However, while Kazakhstan is rich in natural resources with an energy policy attempting to achieve energy independence, its power sector needs considerable rehabilitation and upgrading to improve the efficiency of energy production and use. Kazakhstan's densely populated south has long faced an energy deficit - in stark contrast to the north, which runs on a separate grid that has surplus generating capacity. More than 70\% of Kazakhstan electricity and heating is generated by coal plants located in close proximity to coal mines in northeast Kazakhstan. Although north-south connections for the transfer of power exist, they are insufficient to supply southern demand with major efficiency losses of between $15 \%$ and 33\%.[55] Total available installed capacity thus falls below national energy consumption, especially in the depths of winter and the middle of summer when demand for electric heating and air conditioners grows exponentially. The Ministry of Energy specifically forecasts gradual increase in power shortage in the south every year[56], highlighting the reasons behind the blackout in Almaty, Kazakhstan's largest city with an estimated population of 1.8 million, on July 15, 2019 for over 3 hours.

The question of nuclear power in Kazakhstan has been discussed for many years to produce energy that is $100 \%$ carbon emission-free to overcome the foreseeable electricity deficit. In his 2012 annual state of the nation address, First President Nazarbayev outlined "build up nuclear power industry and construct nuclear power plants" as one of the top ten projects to be implemented in the "Kazakhstan 2050 Strategy".[57] The impulses of the Kazakhstan authorities to construct the nuclear power plant are well understandable: the republic has been the world's leading uranium producer and exporter since 2009, and has possessed a stable and reliable nuclear industry when Kazakhstan and the International Atomic Energy Agency (IAEA) inaugurated the international low-enriched uranium (LEU) Bank Storage Facility in 2017. However, while Kazakhstan's peaceful use of nuclear energy can theoretically boost the republic's capacity to use nuclear diplomacy as a niche, Kazakhstan is a leader in the world's anti-nuclear movement because of its past as a nuclear test site for the Soviet Union. The probability of a nuclear accident is the key factor that makes the public stand against the construction of a nuclear power plant[58], favouring renewable energy development as an environmental-friendly alternative to solve the shortage of energy in the south, diversify its petro-centric economy and bring changes to its petro-state image.

Kazakhstan's topography is suitable for the development of renewable energy. More than $50 \%$ of the country, particularly in the country's northern regions, has average wind speeds of between 4 and 6 metres per second, making them suitable for utility-scale wind farm development, whereas southern Kazakhstan receives consistently high levels of solar irradiation.[59] The latter is particularly meaningful for Almaty as the city is located in the country's south and far from the majority of Kazakhstan's existing power generation facilities. Developing new capacity from renewable energy in both the north and south could limit the need to transmit electricity over large distances and reduce efficiency losses. Although renewable energy is not directly mentioned in the Kazakhstan 2050 Strategy, "search and discovery of energy of the future" was featured separately from nuclear power development as one of the top ten projects.[57]

While renewable energy is at its early stages, Kazakhstan is ramping up policy efforts to incorporate environmentalfriendly energy as part of the country's future. It is one of the first countries in Central Asia to have built an institutional framework to transition to a green economy, having adopted an Ecological Code in 2007, Law on Supporting the Use of Renewable Energy in 2009, and the National Concept of Transition to Green Economy in 2013. Besides, in 2013, the government established the Financial Settlement Centre for Support of Renewable Energy Resources (FSC), a limited liability company registered under KEGOC, to buy all power from renewable energy operators under 15-year power purchase arrangements and then blend the renewable energy electricity to sell to conventional generators. Development of hydropower (especially small hydropower stations), solar and wind is an important component of this transition, and the republic plans to gradually decommission the aging infrastructure, install energy-efficient equipment and comply with strict environmental standards. In an effort to learn from international experiences, Kazakhstan became a member of the IRENA and ratified its charter in 2009. Moreover, it is partnering with international financial institutions such as the European Bank for Reconstruction and Development (EBRD) and the Asian Development Bank (ADB) to bring its policies in line with international standards, reduce the incidence of corruption in key sectors and develop the country's renewable energy infrastructure.[60] The republic's hosting of EXPO2017 under the theme Future Energy was the result of Kazakhstan's years-long efforts to seek a renewable energy future. Although finance remains a challenge for building renewable energy infrastructure in Kazakhstan, changes were 
enacted to the "Law on Supporting the Use of Renewable Energy" with an auction scheme introduced in 2017, opening a gateway for financiers and developers, whom can be both legal entities created in Kazakhstan and foreign legal entities, to bring in investment, technical experiences and latest renewable energy technologies. Auctions are a process, organized and conducted by the auction organizer using an electronic platform, intending to select projects to be constructed and set prices for electricity from renewable energy sources. Moreover, competitive bidding helps drive down prices by increasing cost transparency, leading to reduction of procurement costs for renewable energy purchasers and subsidy costs for the government.

In accordance with the Order of the Minister of Energy, the Kazakhstan Electricity and Power Market Operator (KOREM) joint stock company was named the Organizer of renewable energy auctions. The initial pilot auction, completed in early June 2018, resulted in 194 MW of renewable energy capacity being awarded. In October 2018, the second round of auctions resulted in the award of 664 MW renewable energy capacity.[61] In 2019, the total renewable energy capacity has increased to $1042 \mathrm{MW}$, making up $2.3 \%$ (mainly from solar and wind) of the total installed capacity of all power plants operating in Kazakhstan.[6] The World Energy Council places Kazakhstan at 60th (out of 128 countries) on the 2019 World Energy Security Rankings.[3] Energy diversification is slowly maturing in Kazakhstan's laws and commerce, yet much remains to be done to strengthen the regulatory framework addressing control of emissions, use of renewable resources and increasing energy efficiency measures, while also working to improve public utilities and infrastructure challenge. The Astana International Financial Centre (AIFC), International Centre for Green Technologies and Investments and Astana Hub International IT and Start-ups Hub are some of the most important recent developments in the capital city Nur-Sultan. Fully-fledged in 2018 and located at the EXPO business centre, they were created to be promoting Kazakhstan's accelerated transition to a green economy by fostering technology and best practices, business development and investments.[62]

This brief overview demonstrates Brazil's successful implementation of energy diversification since 50 years ago, while Kazakhstan is a beginner. Both are leading oil exporters in the world, largest in size in their region (South America and Central Asia) and classified as developing countries in need of foreign financial and technological assistance. Their pursuits of energy security via renewable energy sources reflects their common vision in building a sustainable and diversified economy. There are obvious differences in the size of their population, energy intensity and reasons for energy diversification, but Brazil appears to be more prepared for regional electricity cooperation and integration than Kazakhstan does. This contrast provides us an entry to test the validity of neorealism in addressing energy security, both nationally and cooperatively, in an era of energy transition with a large scale of renewable energy deployment added to the energy matrix. This case study of Brazil thus can provide significant reference for Kazakhstan to set its first priority and subsequent steps for an improved energy security, while preparing to approach its national target of increasing renewable energy to $3 \%$ by $2020,30 \%$ by 2030 , and $50 \%$ by 2050 in its energy matrix.

\section{RESULTS AND DISCUSSIONS}

This section presents the results and discussions of the empirical analysis of our hypothesis based on neorealism, namely examining whether regional electricity cooperation and integration are going to be essential to Kazakhstan's pursuit of energy security.

The case study in Brazil indicates that South American countries are increasingly pursuing and benefitting from regional power system integration as an important strategy to help provide reliable, affordable electricity to their economies and citizens. In fact, their cooperative approach demonstrates the common incentives they shared for maximum national power as described by neorealism. Increased electricity cooperation and trade between Brazil and these countries has not only enhanced energy security but brought economies-ofscale in investments, facilitated financing, enabled greater renewable energy penetration, and allowed synergistic sharing of complementary resources. The benefits of this cooperative approach are manifold.

South American member countries in MERCOSUR began to integrate electricity and energy markets, mainly through binational agreements and private activities, when the Tripartite Agreement Corpus-Itaipu was signed by Argentina, Brazil and Paraguay in 1979. Much of the regional electric trade comes from the fact that Argentina, Brazil, Paraguay and neighbour Uruguay share several large hydroelectric dams: Yaciretá, Salto Grande, Chocón and Itaipu; but there are also important power line connections between northern Argentina and Brazil. Development of a portfolio of energy resources for supplying energy along with the development and maintenance of cross-border and domestic oil and gas pipelines, electrical transmission lines, and other such infrastructure are among the aspects of a sound energy security policy. Brazil, due to its geographical position and the size of its energy market, has a decisive role to play in the promotion of regional energy flows.[63] Combining widespread electrification and digital technologies on one hand and renewable power generation on the other can become a central pillar of energy and climate policy, given their numerous benefits. An Inter-American Development Bank report says that if the region increases renewable energy sources to $80 \%$ in its energy matrix and expands cross-border connections, South American countries could save billions of dollars in investments, avoid blackouts and reduce their greenhouse gas emissions.[64] For instance, Brazil's significant wind energy potential at night could be linked with Bolivia's, Peru's and Chile's solar energy potential in the day to create a continuous supply of electricity. Such interdependency via energy diversification further illustrates the common interest for Brazil and its neighbours to achieve energy security and financial benefits as a coalition.

However, analyzing from a neorealist perspective, Brazil's 
readiness to pursue cooperative energy security and integration with its neighbours can also be perceived as the country's attempt to form a regional power bloc in South America under its leadership, counter-balancing U.S. hegemony in South America.[65] Since the early 2000s, especially under former President Lula da Silva (2003-2010), Brazil has set out to strengthen its position as a global player using the South American region as its springboard. To this end, Brazil has been making efforts to strengthen regional cooperation within MERCOSUR. Cooperative energy security, under this circumstance, can be understood as a political means for Brazil to assert itself on the international stage.

It is noteworthy that neorealism also argues that security risks can be produced by the unpredictability of other states. Frequent power cuts in the Brazilian state of Roraima in March 2019 demonstrates the transnational effects of the unrests in Venezuela. Roraima is the only Brazilian state disconnected from the country's national electricity grid. As a result, the northern region has largely depended on the importation of electricity from Venezuela since 2001. The Venezuelan authorities claimed the power cuts were the result of a U.S.-backed cyberattack, while Brazilian newspaper Estado maintained that the power cuts were caused by major strikes over wage debts in the Venezuelan state power corporation Corpoelec.[66] A massive power outage in June 2019 also left swaths of South America at a standstill when lost electricity has been reported in all of Argentina and Uruguay, and parts of Paraguay, Chile, and Southern Brazil. Heavy rains in and around Buenos Aires was to blame but a failure of such epic proportions highlights the vulnerability of the interconnected South American power grid.[67] On this basis, cooperative energy security appears vulnerable in the absence of either infrastructure for efficient connectivity or political stability for a predicable supply to meet the domestic and regional demands. For developing countries of any geographic regions, energy security met by domestic resources should be a priority and remain a component of national capability building until a cooperative regional approach can be adapted when favourable conditions emerge among a group of countries.

Energy relations of Kazakhstan with its neighbours appears to be a reverse of Brazil and MERCOSUR. Power trade and energy interdependence among Central Asian countries have declined dramatically since the collapse of the Soviet Union in 1991. First in 2003, Turkmenistan disconnected from Central Asia Power System (CAPS) and then in 2009, Tajikistan was disconnected from CAPS. As a result, intra-Central Asian electricity trade plummeted by $92 \%$ between 1990 and 2016.[68] This had caused widespread power outages notably in Tajikistan in winter and resulted in increased hydrocarbon fuel use by Kazakhstan, Turkmenistan and Uzbekistan in the summer.

The five nations of Tajikistan, Uzbekistan, Central AsiaKazakhstan, Kyrgyzstan, as well as Turkmenistan - are undoubtedly identifiable as a country, whose member states own more in common with one another than with outside neighbours. Whilst the outbreak of the current regionalism since the 1990s has resulted in the appearance of regional organizations in virtually the entire world regions; a reliable
Central Asian integration project is absent. The Central Asian Cooperation Organization was terminated in 2005, and Kyrgyzstan and Kazakhstan entered the Russian-dominated Eurasian Economic Community and later on the Eurasian Economic Union. Hence, two of the five Central Asian countries engage in some form of regionalism now. However, Central Asia as such is nevertheless one of the few world regions which have not succeeded in establishing a regional organization by itself.

Regarding energy, the current tendency is that each of the five countries wants to ensure reliable and secure electricity to meet their citizens' demand at the lowest cost by utilizing their individual domestic energy resources.[69] Kazakhstan's renewable energy development shares a similar perspective. Despite an increase in foreign investment via energy auctions, the policy makers in the regions have not prioritized an integrated and improved regional power system that would add billions of dollars to the Central Asian economies, enhance energy security, economic stability, and lead to a cleaner environment. As explained by Mr. Bouadokpheng Chansavat, Senior Energy Specialist of The Asian Development Bank (ADB), "the Central Asian countries lack the institutional and technical capacity to optimally coordinate increased power trade, due to prevailing obsolete technologies and system forecast techniques that constraints real-time monitoring of new power system assets in the region and corresponding adjustments of power flows."[70] Smart grid deployment, in this context, is at the heart of the power system evolution as it is inherently related to new technologies and intelligent energy management through the entire value chain from the generation to the consumers. Some industry experts have started calling this trend Energy 4.0 to highlight the magnitude of the transformation they expect will bring to the electric industry. However, according to the United Nations' Department of Economic and Social Affairs, technical planning of a grid interconnection should be coordinated with economic, organizational, legal, and political aspects of a potential interconnection project from the outset of project consideration.[71] The challenge is thus not only subject to technological constrains.

Nevertheless, the United States, through the United States Agency for International Development (USAID), launched the Central Asia Regional Electricity Market (CAREM) project in 2018 to promote the region's long-term energy security and economic growth, while serving as a platform for an expanded Central Asia-South Asia regional power market that will deploy the lowest-cost power in support of greater economic and social development. To date (February 2020), the United States has brought four of the five countries of Central Asia (except Turkmenistan) together to develop a regional energy market. In the next few years, the focus will be on increasing bilateral electricity trade agreements, establishing legal and regulatory agreements, and developing a regional operator and trading platform. At the memorandum of understanding signing In November 2019, USAID Asia Deputy Assistant Administrator Javier Piedra told the then Vice Minister of Energy of Kazakhstan Sungat Yessimkhanov, "we are pleased that your government [Government of Kazakhstan] has agreed with our recommendations on adopting new policy reforms to 
International Journal of Engineering Research and Technology. ISSN 0974-3154, Volume 13, Number 11 (2020), pp. $3718-3731$

(C) International Research Publication House. https://dx.doi.org/10.37624/IJERT/13.11.2020.3718-3731

accelerate renewable energy development. USAID stands ready to provide continued support on improving legislation and other technical assistance to promote the region's longterm energy security and economic growth."[72] From the neorealist perspective with reference to the Brazilian case, Kazakhstan should acknowledge the first priority in building up its own capacity in power generation and infrastructure for transmission and distribution by utilizing the republic's rich conventional and renewable energy reserves in to meet the domestic energy needs and settle the deficit in electricity supply. Regional energy partnership is only beneficial when the interconnected Central Asian power grid is upgraded to accommodate renewable energy sources and conventional power generation for an optimized and consistent electricity output. Energy diversification should be central to the republic's energy integrity and progress in industrialization, a tool for defending its political and economic interests in the foreign arena, and an important factor in ensuring energy security. Renewable energy, in particular, is a technology in which many advanced economies make their investments. Official development assistance in the energy sector is increasingly being directed to renewable energy sources.

Apart from this U.S. initiative, since 2012 the State Grid Corporation of China has looked into the idea of connecting the power generation zones of Western China and Central Asia to the European electricity consumption market by an ultra-high voltage system of several thousand kilometres.[73] Besides enabling local Central Asian population to gain an equal and fair access to electricity, from the neorealism point of view, such concepts of regional electricity integration proposed and facilitated by outside major powers can potentially serve as geopolitical strategies intended to maximize their influence in the region. In fact, Russia and China play a twofold, yet critical role in defining the nature of regional cooperation in Central Asia. More specifically, Russia's more exclusive and deeper regionalism may be contributing to the fragmentation of Central Asia. As for China, its economic power has not been sufficient to foster regional cooperation in Central Asia.[74] The U.S., India and the E.U. have all demonstrated interest in the area, but their engagement, arguably, cannot compare with that of Russia and China. On this basis, the main interests of Central Asian states, such as security, regime survival and perception of common adversary, have the tendency to be laying outside the region, producing a negative impact on the regionalization process. Time will tell if the intermittency of renewable energy and its rapidly growing deployment will become inevitable and strategic for Central Asian states to pursuit cooperative energy security and to facilitate electricity connectivity between China and Europe in the future. In the face of this global trend of energy transition, Kazakhstan should be active and flexible when handling the expansionist energy policy of China and other leading countries and developers in renewable energy with an approach similar to its renowned multi-vector foreign policy, so as not to become critically dependent on individual or groups of countries. Energy diversification, in short, is beyond optimizing energy security and generating clean electricity but creating a new industry, nurturing local specialists and serving as drivers towards a green economy and sustainable development in

\section{Kazakhstan.}

\section{CONCLUSION}

Renewable energy is growing swiftly but fossil fuels continue to dominate the current global energy matrix. Kazakhstan's target of raising the share of renewable energy sources to $50 \%$ by 2050 is more than an internal affair but has significant energy security implications extending to the whole Central Asian region. The era of carbon-intensive energy derived from the burning of fossil fuels is coming to a decline, and a cleaner, more reliable energy future based on renewable energy sources like wind and solar will be the new normal in Kazakhstan in the coming decades. Cutting-edge technologies and innovative approaches are already proposed and showcased in the format of renewable energy auctions for the lowest electric power prices and round-the-clock electricity via regional cooperation. This research paper has demonstrated that energy security of Kazakhstan benefits much from the republic's efforts in diversifying its energy sources with prospects for an increase in foreign direct investment in its local power generation and infrastructure for transmission and distribution, sustainable development and a cooperative approach in dealing with regional issues. Yet, without a drastic upgrade to the domestic and regional infrastructure for energy transmission and distribution, Kazakhstan and Central Asia can become the weakest link of the increasingly interconnected world of renewable energy.

\section{REFERENCES}

[1] Klare, M. T. (2001) "Resource Wars - The new landscape of global conflict" Metropolitan Books, New York.

[2] Cohen, A. (October 18, 2019) "Oil-Rich Kazakhstan Begins The Long March Towards Renewables” Forbes. [Электронный pecypc]. URL: https://www.forbes.com/sites/arielcohen/2019/10/18/oil -rich-kazakhstan-begins-the-long-march-towardsrenewables/\#4ce7733135c6

[3] "Energy Trilemma Index: 2019 Country Rankings" (2019) World Energy Council. Retrieved on February 19, 2020. [Электронный peсурс]. URL: https://trilemma.worldenergy.org/\#!/energy-index

[4] “The National Energy Report 2019” (2019) Kazakhstan Association of Oil, Gas and Energy Sector Organizations. [Электронный pecypc]. URL: http://www.kazenergy.com/upload/document/energyreport/NationalReport19_en.pdf; "List of countries by carbon dioxide emissions per capita" (n.d.) Wikipedia. Retrieved on February 19, 2020. [Электронный pecypc].

URL: https://en.wikipedia.org/wiki/List_of_countries_by_car bon_dioxide_emissions_per_capita

[5] Koch, N. \& Tynkkynen, V. (August, 2018) "Renewables in Kazakhstan and Russia: Promoting 'Future Energy' or Entrenching Hydrocarbon Dependency?” Ponars Eurasia. [Электронный ресурс]. URL: 
https://www.ponarseurasia.org/memo/renewableskazakhstan-russia-future-energy-or-entrenchinghydrocarbon

[6] "In 2019, capacity of renewable energy sources in Kazakhstan doubled" (October 29, 2019) Press service of the Prime Minister of the Republic of Kazakhstan. [Электронный pecypc]. URL: https://primeminister.kz/en/news/za-2019-god-vmoshchnosti-vie-kazahstana-uvelichilis-vdvoe

[7] "Energy Security" (n.d) International Energy Agency. Retrieved on February 19, 2020. [Электронный pecypc]. URL: https://www.iea.org/topics/energysecurity

[8] Routley, N. (October 2, 2019) "Ranked: Countries with the Most Sustainable Energy Policies" Visual Capitalist. [Электронный pecypc].

URL: https://www.visualcapitalist.com/countries-mostsustainable-energy-policies/

[9] Bielecki, Janusz. "Energy security: is the wolf at the door?" The quarterly review of economics and finance 42, no. 2 (2002): 235-250p.

[10] Bohi, D. R., and Toman M. A. (1996) "Implications for Energy Policy" in "The Economics of Energy Security" Kluwer Academic Publishers, 121-130p.

[11] Percebois, J. (February, 2003) "The peaceful uses of nuclear energy: Technologies of the front and backends of the fuel cycle" Energy Policy 31(2), 101-108p.; Gnansounou E. (2008) "Assessing the energy vulnerability: Case of industrialised countries" Energy Policy 36(10) 3734-3744p.

[12] Winzer, C. (2012) "Conceptualizing energy security" Energy Policy, 46, 36-48p.

[13] Sovacool, B., \& Mukherjee, I. (2011) “Conceptualizing and measuring energy security: A synthesized approach" Energy, 36, 5343-5355p.

[14] Egenhofer, C., \& Legge, T. (2001) "Security of supply: A question for policy or markets?” CEPS, Brussels.

[15] Owen, A. D. (2004). Oil supply insecurity: control versus damage costs. Energy Policy, 32(16), 1879$1882 p$.

[16] APERC, Asia Pacific Energy Research Centre (2007) "A Quest for Energy Security in the 21st Century: Resources and Constraints" Institute of Energy Economics, Japan.

[17] Cherp, A; Jewell, J. (2011). The three perspectives on energy security: intellectual history, disciplinary roots and the potential for integration. Current Opinion in Environmental Sustainability, 3, 202-212p.; Jewell, J. \& Cherp, A. (2014). The concept of energy security: Beyond the four As, Energy Policy, vol. 75, 415-421p. https://www.researchgate.net/publication/267634608_T he_concept_of_energy_security_Beyond_the_four_As

[18] Hughes, L. (2009). The Four 'R's of energy security. Energy Policy 37, 2459-2461p.

[19] Dannreuther, R. (2017) "Energy Security” Polity Press, Cambridge.

[20] Gail Cohen, Frederick Joutz, Prakash Loungani, "Measuring Energy Security: Trends in the Diversification of Oil and Natural Gas Supplies," Energy Policy, Volume 39, Issue 9 (2011): 4860-4869p.
[21] Hu, Z. \& Ge, Y. (August 27, 2014) "The Geopolitical Energy Security Evaluation Method and a China Case Application Based on Politics of Scale" Sustainability 2014, 6(9), 5682-5696p. [Электронный ресурс]. URL:https://www.mdpi.com/2071-1050/6/9/5682

[22] IRENA (2019) “A New World: The Geopolitics of the Energy Transformation" Global Commission on the Geopolitics of Energy Transformation. [Электронный pecypc]. URL: https://irena.org//media/Files/IRENA/Agency/Publication/2019/Jan/Glo bal_commission_geopolitics_new_world_2019.pdf

[23] Yergin, D. (1991) "The prize: The epic quest for oil, money, and power" Simon \& Schuster, New York; Yergin, D. (2006) "Ensuring Energy Security" Foreign Affairs, Volume 85, No.2, 2006.

[24] Shaffer, B. (2009) "Energy Politics" University of Pennsylvania Press, Philadelphia.

[25] Müller-Kraenner, S. (2008) "Energy Security" Earthscan Publishing, London.

[26] Scholten, D ed. (2018) "The Geopolitics of Renewables" Springer International Publishing.

[27] Hache, E. (2018) "Do renewable energies improve energy security in the long run?" IFP Energies Nouvelle.

https://www.ifpenergiesnouvelles.fr/sites/ifpen.fr/files/i nline-

images/NEWSROOM/Regards $\% 20 \% \mathrm{C} 3 \%$ A9conomiq ues/Notes\%20de\%20conjoncture/Cahiers\%20de\%201' \%C3\%A9conomie/ECO109_HACHE.pdf

[28] IRENA, OECD/IEA and REN21 (2018) "Renewable Energy Policies in a Time of Transition" International Renewable Energy Agency, Organization for Economic Co-operation and Development, International Energy Agency, Renewable Energy Policy Network for the 21st Century. [Электронный pecypc]. URL: https://www.irena.org//media/Files/IRENA/Agency/Publication/2018/Apr/IR ENA_IEA_REN21_Policies_2018.pdf

[29] IRENA (2019) "A New World: The Geopolitics of the Energy Transformation" Global Commission on the Geopolitics of Energy Transformation. [Электронный pecypc]. URL: https://irena.org//media/Files/IRENA/Agency/Publication/2019/Jan/Glo bal_commission_geopolitics_new_world_2019.pdf

[30] Ölz, S., Sims, R., \& Kirchner, N. (2007). Contribution of renewables to energy security. Paris: IEA Information Paper. [Электронный pecypc]. URL: https://webstore.iea.org/download/direct/919

[31] Johansson, B. (October 6, 2013) "Security aspects of future renewable energy systems: A short overview" Energy 61 (2013) 598-605p. [Электронный ресурс]. URL:

https://www.sciencedirect.com/science/article/pii/S036 0544213007743

[32] Abolhosseini, S., Heshmati, A. \& Altmann, J. (April, 2014) "A Review of Renewable Energy Supply and Energy Efficiency Technologies” Discussion Paper No. 8145, Institute for the Study of Labor. [Электронный pecypc]. URL: http://ftp.iza.org/dp8145.pdf 
[33] "The Role of Renewable Energy in National Security" (October 2018) ACORE. https://acore.org/wpcontent/uploads/2018/10/ACORE_Issue-Brief_-TheRole-of-Renewable-Energy-in-National-Security.pdf

[34] Scholten, D ed. (2018) "The Geopolitics of Renewables" Springer International Publishing.

[35] Fares, R. (March 11, 2015) "Renewable Energy Intermittency Explained: Challenges, Solutions, and Opportunities" Scientific American. [Электронный pecypc].

URL:

https://blogs.scientificamerican.com/plugged-

in/renewable-energy-intermittency-explained-

challenges-solutions-and-opportunities/

[36] Proaño, M. (November 11, 2018) "Brazilian energy under Bolsonaro's government: Brazil above all?" Energy Transition. [Электронный pecypc]. URL: https://energytransition.org/2018/11/brazilian-energy/

[37] "Energy Policy in Brazil: Perspectives for the medium and long term" (May, 2014) Swedish Agency For Growth Policy Analysis. [Электронный pecypc]. URL: https://www.tillvaxtanalys.se/download/18.201965214 d8715afd113b87/1432548740127/Energisystem\%2Bbo rtom\%2B2020\%2BBrasilien.pdf

[38] Pereira, G. M. et al (2012) "The renewable energy market in Brazil: Current status and potential" Renewable and Sustainable Energy Reviews, Volume 16, Issue 6, August 2012, 3786-3802p.

[39] Santos, T. (2018) "Regional Energy Security: Reevaluating Concepts and Policies to Promote Energy Integration in MERCOSUR" UFRJ, Rio de Janeiro. [Электронный pecypc]. https://www.academia.edu/36238041/REGIONAL_EN ERGY_SECURITY_RE-

EVALUATING_CONCEPTS_AND_POLICIES_TO_ PROMOTE_ENERGY_INTEGRATION_IN_MERCO SUR

[40] Zhiyenbayev, M. et al (October 3, 2018) "Economic and Energy Security of the Republic of Kazakhstan" International Journal of Energy Economics and Policy, 2018, 8(6), 16-21p. [Электронный ресурс]. URL: https://www.academia.edu/38668527/Economic_and_E nergy_Security_of_the_Republic_of_Kazakhstan

[41] Mantel, R. (Winter, 2016) "Energy Security Strategy in Kazakhstan: Environmental Security and Renewable Energy Sources" Energy Security in the Caucasus and Central Eurasia, Caucasus International, Vol. 6, No: 2, Winter 2016. [Электронный pecypc]. URL: https://www.academia.edu/35936222/Renata_Mantel_ Energy_Security_Strategy_in_Kazakhstan_Environme ntal_Security_and_Renewable_Energy_Sources_

[42] Трачук, K. V. (n.d.) “Современные исследования проблем энергетической безопасности: теоретические аспекты" Cyber Leninka. Retrieved on February 19, 2020. [Электронный ресурс]. URL: https:/cyberleninka.ru/article/n/sovremennyeissledovaniya-problem-energeticheskoy-bezopasnostiteoreticheskie-aspekty; Waltz K. (1979) "Theory of international politics" Reading, MA, Addison-Wesley Publ., 251p.; Aron R. Paix et guerre entre les nations
(1962) "War and peace between nations" Paris, Calmann-Levy ed., 1962. 794p.

[43] Mearsheimer, J. (2001). "The tragedy of great power politics" W.W. Norton \& Company, New York; Morgenthau H. et al. (1948) "Politics Among Nations: The Struggle for Power and Peace" McGraw-Hill Education; New York; Treverton, G. \& Jones, S. (2005) "Measuring National Power" RAND National Security Research Division. [Электронный pecypc]. URL: https://www.rand.org/content/dam/rand/pubs/conf_proc eedings/2005/RAND_CF215.pdf; Waltz, K. (1999) "Realism: The State, Power, and the Balance of Power" in Viotti \& Kauppi ed. (1999) "International Relations Theory: Realism, Pluralism, Globalism, and Beyond" Pearson, 161-162p.

[44] "China's Thirst For Crude Oil Pushes Brazil's December Exports To All-Time High" (January 23, 2019) Hellenic Shipping News Worldwide. [Электронный pecypc]. URL: https://www.hellenicshippingnews.com/chinas-thirstfor-crude-oil-pushes-brazils-december-exports-to-alltime-high/

[45] De Oliveira, A. (1988) "Choosing energies in Brazil: Sugar or oil?” Appropriate Technology Vol. 15. No. 3, 1988.

[46] De Oliveira, A. (2010) "Energy Security in South America" International Institute for Sustainable Development. [Электронный pecypc]. URL: https://pdfs.semanticscholar.org/c99e/6599565d5ea524 3cdb5750c28a867d56b2a5.pdf

[47] "World Development Indicators, Brazil" (n.d.) World Bank. Retrieved on February 19, 2020. [Электронный pecypc]. https://databank.worldbank.org/source/worlddevelopment-indicators

[48] Electrobras. (2013) "Plano Annual do PROINFA (Annual Plan of PROINFA)" Electrobras, Rio de Janiero.

[49] Renewable Energy World Editors (May 31, 2019) "Brazil plans to add more solar to its hydro-dominated electricity generation mix" Renewable Energy World. [Электронный pecypc]. URL: https://www.renewableenergyworld.com/2019/05/31/br azil-plans-to-add-more-solar-to-its-hydrodominatedelectricity-generation-mix/

[50] "Energy" (October 13, 2019) International Trade Administration. [Электронный pecypc]. URL: https://www.trade.gov/knowledge-product/brazilenergy

[51] Global Environment Facility and Factor (2017) "Renewable Energy Auctions in Latin America and the Caribbean" [Электронный pecypc]. URL: https://www.wearefactor.com/docs/RE_LAC.pdf

[52] Exenberger, M (2016) "Energy systems of the future in Brazil" GIZ. [Электронный pecypc]. URL: https://www.giz.de/en/worldwide/12565.html; "China wants to strengthen Brazil ties, investing heavily in the energy sector" (September, 2017) Apex-Brasil. [Электронный pecypc]. URL: http://www.bebrasil.com.br/en/news/china-wants-to- 
International Journal of Engineering Research and Technology. ISSN 0974-3154, Volume 13, Number 11 (2020), pp. 3718-3731

(C) International Research Publication House. https://dx.doi.org/10.37624/IJERT/13.11.2020.3718-3731

strengthen-brazil-ties-investing-heavily-in-the-energysector

[53] "Energy" (October 13, 2019) International Trade Administration. [Электронный pecypc]. URL: https://www.trade.gov/knowledge-product/brazilenergy

[54] Workman, D. (December 23, 2019) "Coal Exports by Country” World's Top Exports. [Электронный pecypc]. URL: http://www.worldstopexports.com/coalexports-country/; Workman, D. (February 4, 2020) "Crude Oil Exports by Country" World's Top Exports. [Электронный pecypc]. URL: http://www.worldstopexports.com/worlds-top-oilexports-country/; Workman, D (February 7, 2020) "Petroleum Gas Exports by Country" World's Top Exports. [Электронный pecypc]. URL: http://www.worldstopexports.com/petroleum-gasexports-country/

[55] Kadrzhanova A. (December, 2013) "Kazakhstan: Power Generation and Distribution Industry" The U.S. Commercial Service. [Электронный ресурс]. URL: http://www.iberglobal.com/files/kazajstan_power.pdf

[56] Akayeva K. (October 31, 2019) "The Future of Kazakhstan: Atom for Peace or Wind and Solar Power?" Central Asian Bureau for Analytical Reporting. [Электронный pecypc]. URL: https://cabar.asia/en/the-future-of-kazakhstan-atom-forpeace-or-wind-and-solar-power/

[57] "Kazakhstan 2050 Strategy" (n.d.) Wikipedia. Retrieved on February 19, 2020. [Электронный pecypc].

URL: https://en.wikipedia.org/wiki/Kazakhstan_2050_Strateg $\mathrm{y}$

[58] Maitre, E. (July 1, 2018) 'Kazakhstan's nuclear policy: an efficient niche diplomacy?" Fondation pour la Recherche Stratégique. [Электронный ресурс]. URL: https://www.frstrategie.org/en/publications/notes/kazak hstans-nuclear-policy-efficient-niche-diplomacy-2018; Nurysheva, G. et al. (October 19, 2019) "The Kazakh Ethical Tradition and Anti-nuclear Ethics" Springer Link. [Электронный pecypc]. URL: https://link.springer.com/chapter/10.1007/978-3-03024021-9_4; Akayeva K. (October 31, 2019) "The Future of Kazakhstan: Atom for Peace or Wind and Solar Power?" Central Asian Bureau for Analytical Reporting. [Электронный pecypc]. URL: https://cabar.asia/en/the-future-of-kazakhstan-atom-forpeace-or-wind-and-solar-power/

[59] Wheeler, E. (May 2, 2017) “Kazakhstan's Renewable Energy Quest” The Diplomat. [Электронный pecypc]. URL: https://thediplomat.com/2017/05/kazakhstansrenewable-energy-quest/

[60] Berdikeeva, S. (September 12, 2018) "Feature: Kazakhstan's green energy future" Energy Digital. [Электронный pecypc]. URL: https://www.energydigital.com/renewableenergy/feature-kazakhstans-green-energy-future

[61] "Support for the Implementation of Wind Auctions in Kazakhstan" (n.d.) European Bank for Reconstruction and Development. Retrieved on February 19, 2020.
[Электронный pecypc].

URL:

https://www.ebrd.com/work-with-

us/projects/tcpsd/support-for-the-implementation-ofwind-auctions-in-kazakhstan.html

[62] Satubaldina, A. (n.d.) "EXPO 2017's legacy continues to move Kazakhstan, international community toward a greener future" Edge. [Электронный ресурс]. URL: https://www.edgekz.com/expo-2017s-legacy-continuesto-move-kazakhstan-international-community-towarda-greener-future/

[63] De Oliveira, A. (2010) "Energy Security in South America" International Institute for Sustainable Development. [Электронный pecypc]. URL: https://pdfs.semanticscholar.org/c99e/6599565d5ea524 3cdb5750c28a867d56b2a5.pdf

[64] Viscidi, L. \& Yepez, A. (February 1, 2018) "The energy solution Latin America Needs" The New York Times. [Электронный pecypc]. URL: https://www.nytimes.com/2018/02/01/opinion/energygrid-latin-america.html

[65] Wigell, M. (May, 2011) "Assertive Brazil: an emerging power and its implications" FIIA Briefing Paper 82, The Finnish Institute of International Affairs. [Электронный pecypc]. URL: https://www.files.ethz.ch/isn/129601/bp82.pdf

[66] Foggin, S. (March 26, 2019) "Why Venezuela's power outage is also a Brazilian problem" Latin America Reports. [Электронный pecypc]. URL: https://latinamericareports.com/why-venezuelasapagon-is-also-a-brazilian-problem/1515/

[67] Livni, E. (16 June, 2019) "50 million people lose electricity in South American blackout" Quartz. [Электронный pecypc]. URL: https://qz.com/1645362/50-million-lose-power-insouth-america-blackouts/

[68] Russell, M. (April 2019) “Connectivity in Central Asia: Reconnecting the Silk Road" European Parliament. [Электронный pecypc]. URL: https://www.europarl.europa.eu/RegData/etudes/BRIE/ 2019/637891/EPRS_BRI(2019)637891_EN.pdf

[69] "A game changer in the Central Asia regional electricity market" (November 24, 2019) USAID. [Электронный pecypc]. URL: https://www.usaid.gov/central-asia-regional/ourstories/nov-2019-game-changer-central-asia-regionalelectricity-market

[70] "ADB Grant to Support Increased Cross-Border Energy Trading in Central Asia" (January 7, 2019) Asian Development Bank. [Электронный pecypc]. URL: https://www.adb.org/news/adb-grant-supportincreased-cross-border-energy-trading-central-asia

[71] "The Potential of Regional Power Sector Integration" (April, 2010) Economic Consulting Associates. [Электронный pecypc]. URL: http://documents. worldbank.org/curated/en/456981468 154776209/pdf/773070v130ESMA0he0Potential0of0R PSI.pdf

[72] "USAID implements Central Asia Regional Electricity Market project" (October 31, 2019) Strategeast. [Электронный pecypc].

URL: 
International Journal of Engineering Research and Technology. ISSN 0974-3154, Volume 13, Number 11 (2020), pp. 3718-3731

(C) International Research Publication House. https://dx.doi.org/10.37624/IJERT/13.11.2020.3718-3731

https://www.strategeast.org/usaid-implements-centralasia-regional-electricity-market-project/

[73] Mazzucchi, N. (September 11, 2018) "China and European electricity networks: strategy and issues" Fondation pour la recherche stratégique [Электронный pecypc].

URL: https://www.frstrategie.org/en/publications/notes/chinaeuropean-electricity-networks-strategy-issues-2018

[74] Krasnopolsky, P. (January 25, 2016) "Major powers and regionalism in Central Asia" CASI Research Seminar, American University of Central Asia. [Электронный pecypc]. URL: http://web.isanet.org/Web/Conferences/GSCIS\%20Sin gapore\%202015/Archive/8e26ebb3-f4a3-4a13-ac59adb0ee445aa5.pdf 